\title{
Diastolic function changes of the left and right ventricle after heart transplantation
}

\author{
(D)Jana Ljubas Maček*, \\ (D)Marija Mance, \\ (D)Marijan Pašalić, \\ DVlatka Rešković \\ Lukšić, \\ DIvo Planinc, \\ DNina Jakuš, \\ (DBoško Skorić, \\ (D)Jure Samardžić, \\ (DDaniel Lovrić, \\ (DMaja Čikeš, \\ DHrvoje Jurin, \\ DDora Fabijanović, \\ DDavor Miličić, \\ DDJadranka Šeparović \\ Hanževački
}

University of Zagreb School of Medicine, University Hospital Centre Zagreb, Zagreb, Croatia

RECEIVED:

February 28, 2019

ACCEPTED:

March 24, 2019

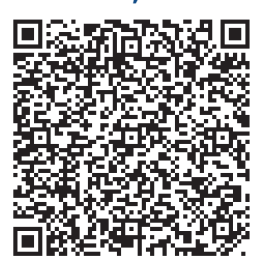

$\square$ Cardiologia Croatica 2019;14(3-4):96.
KEYWORDS: heart transplantation, diastolic function, donor age, pulmonary hypertension, acute right ventricular failure

CITATION: Cardiol Croat. 2019;14(3-4):96. | https://doi.org/10.15836/ccar2019.96

*ADDRESS FOR CORRESPONDENCE: Jana Ljubas Maček, Klinički bolnički centar Zagreb, Kišpatićeva 12, 10000 Zagreb, Croatia. / Phone: +385-098-577-707 / E-mail: janaljubas@yahoo.com

ORCID: Jana Ljubas Maček, https://orcid.org/0000-0001-7171-2206 • Marija Mance, https://orcid.org/0000-0003-1542-2890 Marijan Pašalić, https://orcid.org/0000-0002-3197-2190 • Vlatka Rešković Lukšić, https://orcid.org/0000-0002-4721-3236 Ivo Planinc, https://orcid.org/0000-0003-0561-6704 • Nina Jakuš, https://orcid.org/0000-0001-7304-1127 Boško Skorić, https://orcid.org/0000-0001-5979-2346 • Jure Samardžić, https://orcid.org/0000-0002-9346-6402 Daniel Lovrić, https://orcid.org/0000-0002-5052-6559 • Maja Čikeš, https://orcid.org/0000-0002-4772-5549 Hrvoje Jurin, https://orcid.org/0000-0002-2599-553X • Dora Fabijanović, https://orcid.org/0000-0003-2633-3439 Davor Miličić, https://orcid.org/0000-0001-9101-1570 • Jadranka Šeparović Hanževački, https://orcid.org/0000-0002-3437-6407

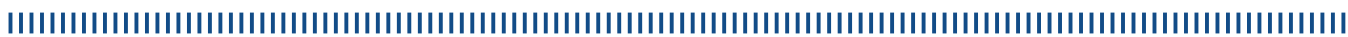

Background: A new hemodynamic environment is set up after heart transplantation (HTx).,12 Our aim was to assess changes in diastolic function of the left (LV) and right (RV) ventricle in HTx patients (Pts) during the $1^{\text {st }}$ year and the influence of donor age, graft ischemic time (GIT) and acute right ventricular failure (ARVF).

Patients and Methods: In 55 "healthy" HTx Pts echo was performed 1- and 12 months after HTx. Data on mitral valve (MV) E- (Ew) and A-wave velocity (Aw), MV and tricuspid (TV) E/A ratio, MV and TV E' and $\mathrm{A}^{\prime}$ by tissue Doppler, septal E/E', pulmonary vein diastolic velocity (PVd), systolic pulmonary pressure (sPAP), left atrial indexed volume (LAVI), right atrial pressure (RAP) were collected.

Results: Ew significantly decreases during the $1^{\text {st }}$ year $(0.80 \mathrm{vs} .0 .73 \mathrm{~m} / \mathrm{s} ; \mathrm{p}=0.036)$ as well as E/E' (11.5 vs. 9.1; $p=0.009$ ), PVd (0.67 vs. $0.55 \mathrm{~m} / \mathrm{s} ; \mathrm{p}<0.001)$ and sPAP (33 vs. $26 \mathrm{mmHg} ; \mathrm{p}<0.001$ ) without concomitant significant change in Aw $(\mathrm{p}=0.855)$ and LAVI $(\mathrm{p}=0.060)$. TV E/A, TV-E'and TV-A' show no significant change. Pts with significant pulmonary hypertension (PAH) in the $1^{\text {st }}$ month have higher Ew (0.90 vs. $0.75 \mathrm{~m} / ; \mathrm{p}=0.021), \mathrm{E} / \mathrm{A}$ (2.2 vs. 1.7; $\mathrm{p}=0.034)$ and $\mathrm{E} / \mathrm{E}^{\prime}$ (14 vs. 10; $\mathrm{p}=0.047$ ) but after 1-year only elevated mitral E/A (2.2 vs. 1.6; $p=0.014$ ), without change in LAVI ( $p=0.095)$. Higher donor age ( $>$ mean of 41 years) caused initially lower MV-E' (r=-0.390, $\mathrm{p}=0.010)$ and higher $\operatorname{sPAP}(\mathrm{r}=0.285 ; \mathrm{p}=0.045)$. GIT had no influence on diastolic parameters. ARVF significantly correlated with lower TV-A' acutely and after 1 year (ARVF 5 vs. no-ARVF $8 \mathrm{~cm} / \mathrm{s} ; \mathrm{r}=-0.600, \mathrm{p}=0.011)$ and higher RAP $(\mathrm{r}=0.414, \mathrm{p}=0.003)$.

Conclusion: During the $1^{\text {st }}$ postransplant year there is improvement in LA diastolic function with better early passive LV filling and reduction in PAH, without change in active filling phase or LA volume. In Pts with significant PAH mean E/E' ratio within $1^{\text {st }}$ month was 14 , but after a year in Pts with persistent PAH it declines to only 10, preserving the higher E/A ratio. Higher donor age could impair the early LV ventricular filling with a trend toward more PAH but MV-E' improves with time. ARVF reduces active RV filling (TV-A') throughout the 1st year. GIT does not have influence on diastole.

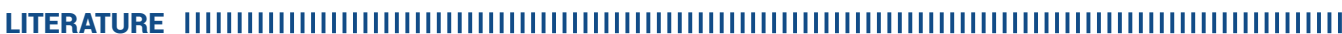

1. Broch K, Al-Ani A, Gude E, Gullestad L, Aakhus S. Echocardiographic evaluation of left ventricular filling pressure in heart transplant recipients. Scand Cardiovasc J. 2014 Dec;48(6):349-56. https://doi.org/10.3109/14017431.2014.981579

2. López B, Sanchez V, Delgado JF, Casares SF, Mora L, García J, et al. Accuracy of noninvasive estimation of pulmonary wedge pressure by echocardiographic indices in heart transplant recipients. Transplant Proc. 2012 Nov:44(9):2639-41.

https://doi.org/10.1016/j.transproceed.2012.09.058 